\title{
Invasive plant species and their disaster-effects in dry tropical forests and rangelands of Kenya and Tanzania
}

John F. Obiri

Masinde Muliro University of Science \& Technology Centre of Disaster Management \& Humanitarian Assistance

Research, Development and Documentation Dept.

Jafobiri@gmail.com

\section{ABSTRACT}

Invasive plants are a hazard in the tropical dry forests and rangelands of East Africa. Although often not reported, they have increasingly created disasters that have affected the environment and socio-economic wellbeing of communities inhabiting these dry regions. This paper reports on the key invasives in the drylands of Kenya and Tanzania and their effects, and suggests some disaster risk reduction (DRR) strategies. The study was largely based on secondary data analysis and supported by surveys in the affected drylands. The findings show ten key invasive plant species that affect the drylands. Their disaster-effects vary and include: causing the death of livestock by poisoning and destroying livestock foliage, accelerating biodiversity loss via suppression of native plants, to increasing diseases by offering a breeding ground for mosquitoes and other insects that carry ailments like nagana and sleeping sickness.

The DRR initiatives include (1) having a prudent land use system that discourages activities like unplanned burning of drylands, (2) assessing and monitoring phytosanitary risks associated with introduced plant species, (3) strengthening national and local institutional capacities that enhance invasive species awareness and preparedness for disasters, and (4) enhancing early warning systems related to plant invasion.

\section{KEYWORDS}

disaster risk reduction, invasive species, drylands, East Africa and slow onset disasters

\section{Introduction}

A looming disaster that has been poorly reported and at times neglected is the loss of biodiversity across the East African dry forests and rangelands. The biodiversity of dry lands offers tremendous socio-economic and environmental benefits to society. These include the provision of direct goods and services such as foods, medicines, timber, fuelwood, tourism and indirect services such as climate regulation, water catchment protection and soil conservation. Inevitably the decline and loss of this biodiversity has ultimately led to certain societal disasters (Rejmanek, 1995; Pimentel, 2002; Mooney et al., 2003). Biodiversity loss, particularly the decline of 
plants, has been associated with deforestation, land degradation, climate change effects and spread of invasive alien species. Some of these invasive species have caused considerable disasters in East African dry forests and rangelands (Wakibara \& Mnaya, 2002; Pasiecznik et al., 2006; Kenya Law Report, 2007a; IUCN, 2010). The United Nation Environmental Programme (UNEP) estimates that alien invasive species cost the global economy an annual US \$1.4 trillion. In Africa limited studies have been done to quantify the cost of invasive plants species. However, studies in South Africa alone show the country spends over $\$ 60$ million annually to eradicate invasive plants (Enviro-Conserve, 2010).

Like many areas globally, invasive species in the dry forests and rangelands (which are hereafter jointly referred to as drylands) of East Africa have been introduced both intentionally and accidentally and are damaging the natural and man-made ecosystems. In East Africa, and particularly Kenya, pastoralists have been adversely affected and disasters registered in many communities. For instance, in 2006, following the heavy livestock losses caused by the invasive plant Prosopis juliflora or Mesquite, communities of Baringo, Kenya, instituted a constitutional case against the government of Kenya for introducing Mesquite in their environment (Kenya Law Report, 2007b). The communities pointed out a pack of disasters that befell them as a result of the mesquite tree (Kenya Law Report, 2007b). These include the lack of water around Lake Baringo due to the colonisation of mesquite on the lake shores and human diseases such as asthma, lung inflammation and allergies.

Invasive plant invasion is a man-made and slow onset disaster (SOD) that is least noticed, often forgotten and neglected. Several reasons are given as to why disasters caused by invasive plant species are often neglected. These include the fact that the disaster-impacts arising from invasive plants are often considered not high enough to attract the attention of the media and disaster managers. Another factor is that disasters of invasive plants are often misunderstood (Pasiecznik et al., 2006). As such they are among the neglected and under-reported disasters (Pidot, 2005; Krueger, 2007; Wisner \& Gaillard, 2009). This paper reports on the invasive wood plant species found in the drylands of Kenya and Tanzania and looks at their disaster-impacts. It explores the process of invasion, particularly the opportunities that facilitate invasion and in doing so seeks to understand and thus "reduce the underlying risk factor" as pointed by the Hyogo Framework for Action priority 4. Coupled to the latter, the paper further suggests disaster risk reduction (DRR) strategies that will limit invasions and their associated disasters.

\section{Research methodology}

The study was undertaken in two regions of East Africa. These were in the drylands of northern Kenya in an area called the Baringo District and in the Morogoro area of Central Tanzania. Within the Baringo district, the study was largely confined to the Marigat Division, which covers an area of $1,276 \mathrm{~km}^{2}$ between latitudes $0^{\circ} 20^{\prime} \mathrm{N}$ and $0^{\circ} 44^{\prime} \mathrm{N}$ and longitudes $35^{\circ} 57^{\prime} \mathrm{E}$ and $36^{\circ} 12^{\prime} \mathrm{E}$. In Tanzania the study was confined to the Morogoro Region of latitudes 6 $6^{0} 34^{\prime} \mathrm{S}$ and $6^{0} 45^{\prime} \mathrm{S}$ and longitudes $37^{\circ} 53^{\prime} \mathrm{E}$ and $38^{\circ} 04^{\prime} \mathrm{E}$. Although in different countries, these study areas have similar socio-economic and environmental characteristics that include low incomes, prevalent poverty, pastoralism and poor natural resource management that has led to increased environmental degradation such as deforestation, invasive species and soil erosion. It is the 
prevalence of these factors and their close link to invasive plant species that led to the choice of these study sites.

In both study areas primary and secondary data sources were used. Primary data largely involved field surveys in the areas where invasive species were prevalent. A list of woody plant species in these drylands was compiled focusing on those species whose quantities or population had increased by over $75 \%$ during the past three decades, and which were thus suspected to be highly invasive. The basis of determing plants that had greatly increased in population was established by comparing current records of the plant population with similar old records existing in the areas in the mid-1980s. For the Baringo area in Kenya, these records were available from the Kenya Forestry Research Institute and the Kenya Forestry Service. For the Morogoro area (Tanzania), records were obtained from the archives of the Ministry of Environment and Natural Resources and the Faculty of Forestry at the Sokoine University of Agriculture - both institutions are based in the Morogoro region and are active in dryland forest management. This information was compared with that obtained from inhabitants of the two regions who had lived there and had knowledge of the region from the 1980s. In both cases the inhabitants involved were local village elders and questionnaire interviews were used to obtain the information. The questionnaires sought information on the occurrences of invasive plants and their disaster-impacts. This was compared with data collected in the field survey and from forestry records earlier mentioned (i.e. secondary data). A checklist of species in the two study areas was developed and their disaster-impacts compared.

\section{Findings}

\section{Invasive woody species in Kenyan and Tanzanian drylands and their disaster effects}

Only limited studies have been done on invasive species in Africa. The Invasive Woody Plant Database (with over 5000 publications on species invasiveness) has only $6 \%$ referring to tropical Africa. Of the few reports and studies done in East Africa, Lantana camara (commonly referred to as Lantana) is the most widely distributed invader (Table 1). Eight species considered invasives were found to be common to both the drylands of Kenya and Tanzania (Table 1). The most common were Psidium guajava (Guava tree), Prosopis juliflora (Mesquite), Opuntia ficus indica (Prickly pear cactus) and Lantana camara (Lantana). The driest parts of East Africa have the least number of reports despite covering the largest area (Binggeli et al., 1998).

In both Kenya and Tanzania there is a plethora of laws governing the management of invasive species. Among the key laws in Kenya are the Environmental Management and Coordination Act (EMCA), the Seeds and Plant Variety Act, the Agricultural Produce Act and the Plant Protection Act which are largely implemented through the National Environmental Management Authority (NEMA). In Tanzania there are the Forest Act No. 14 of 2002, the Plant Protection Act of 1997, the National Disaster Management Policy of 2004 and the Environmental Management Act No. 20 of 2004 that are mainly administered via the Ministry of Environment and Natural Resources (MENR). Despite these laws and institutions, the invasion of plant species continues to be a threat and key contributor to environmental disasters in the drylands. The occurrence of invasives is mainly the result of the unauthorised and poorly planned introduction and movement of plant materials. 
In Kenyan drylands the major reported invader is Mesquite. This is one of the most widespread dryland invasive species in north and east Africa, having already invaded 500000 and 700000 hectares in Kenya and Ethiopia, respectively. Under ideal conditions, it has the ability to double its range every 5 years (IUCN, 2010). Although initially introduced to stabilise the drylands by revegetating barren land, Mesquite went on to outcompete and replace the native plants and trees. It has been blamed for many disaster-effects such as replacing the foliage (grasses, herbs and shrubs) eaten by local livestock, injuring livestock with its poisonous thorns and causing goat teeth to rot and fall out because the small seeds get stuck between the teeth (Table 1). Thousands of goats have been rendered toothless and died from starvation following teeth loss. In addition the roots of Mesquite make the soil loose and unable to sustain water; thus enhancing drought and soil erosion. Furthermore, because of its aggressive growth the plant forms thickets that are an ideal breeding ground for mosquitoes that transmit malaria. Another serious invasive plant is the prickly pear cactus or Opuntia ficus indica. This plant, which has been blamed for destroying grazing land in the Kenyan and Tanzanian drylands, is originally from Mexico. It was introduced as a hedge plant but has become a serious and difficult to control pest, because it spreads rapidly degrading the dry lands. Other prolific woody invasive plant species include the Lantana and the Acacia polycantha (White thorn) tree. All these invasive plants and trees have had serious socio-economic impacts and ultimately increased poverty in the local communities.

In the Tanzanian drylands two species have been largely reported as weedy or invasive: Senna spectabilis or Cassia (Wakibara \& Mnaya, 2002) and the White thorn (Obiri et al., 2010). These species suppress the growth of native trees, shrubs and grasses growing beneath or close to them. Subsequently foliage for wildlife animals is reduced leading to starvation and death of the animals. Although there are few invasive species in Tanzania there is no guarantee that the numbers will remain so in the future. A species that is not invasive today can in the future turn into an invader with disastrous effects.

Some introduced plants and tree species have been known to remain in small localized populations for long periods of time but later turn into burgeoning populations of invasives (Kolar \& Lodge, 2001). The time period between the first introductions of a species in a new location and when it is declared invasive varies with different species and is referred to the species time lag. This time lag is largely responsible for why invasive plant species show slow onset disasters or SOD characteristics. Slow onset disasters are a category of disasters whose impact on the environment is not felt immediately but often takes time to build up. Common examples include drought and its effects of crops failure and famine. Similarly, heavy rains in a highland area can be followed later by flooding in a lowland area elsewhere. In both cases there is a lag in time between the onset of the disaster and the effects to be felt. For invasive tree species a typical example is found in the Usambara Mountains of Tanzania where the Maesopsis eminii (or Msira) tree was declared invasive and a disaster to the forest ecosystem 65 years after it was first introduced in 1913 (Binggeli, 1989). More recently Mesquite has been declared a serious invader in Kenyan drylands twenty years after its first introduction in the early 1980s (Pasiecznik et al., 2006). 
Invasive plant species and their disaster-effects in dry tropical forests and rangelands of Kenya and Tanzania

Table 1. Incidences of invasive plants and their disaster effects in Kenyan and Tanzanian drylands. Plant occurrence indicated by the + symbol. Common names are put in brackets.

\begin{tabular}{|c|c|c|c|}
\hline & $\begin{array}{l}\text { Occurrence in } \\
\text { Tanzania }\end{array}$ & $\begin{array}{l}\text { Occurrence } \\
\text { in Kenya }\end{array}$ & Disaster effects / impacts \\
\hline $\begin{array}{l}\text { Lantana camara } \\
\text { (Lantana) }\end{array}$ & + & + & $\begin{array}{l}\text { Breeding ground for sleeping sickness \& } \\
\text { Nagana, disrupts plant succession \& lowers } \\
\text { biodiversity }\end{array}$ \\
\hline $\begin{array}{l}\text { Prosopis juliflora } \\
\text { (Mesquite) }\end{array}$ & + & + & $\begin{array}{l}\text { Reduces livestock foliage, deep roots enhance } \\
\text { drought, thorns poisonous }\end{array}$ \\
\hline $\begin{array}{l}\text { Prosopis pallida } \\
\text { (Mesquite) }\end{array}$ & & + & $”$ \\
\hline $\begin{array}{l}\text { Opuntia ficus indica } \\
\text { (Prickly pear cactus) }\end{array}$ & + & + & $\begin{array}{l}\text { Poisonous to wildlife in parks, affecting potential } \\
\text { of tourism }\end{array}$ \\
\hline $\begin{array}{l}\text { Caesalpinia decapetala } \\
\text { (Mauritius thorn) }\end{array}$ & + & + & $\begin{array}{l}\text { Shades out grass \& shrubs eaten by animals, } \\
\text { limits animal movement }\end{array}$ \\
\hline $\begin{array}{l}\text { Psidium guajava } \\
\text { (Guava) }\end{array}$ & + & + & $\begin{array}{l}\text { Outcompetes native plants and lower species } \\
\text { biodiversity }\end{array}$ \\
\hline $\begin{array}{l}\text { Senna spectabilis } \\
\text { (Cassia) }\end{array}$ & + & & Suppresses growth of native park trees \\
\hline $\begin{array}{l}\text { Acacia farnesiana } \\
\text { (Sweet acacia) }\end{array}$ & + & + & $\begin{array}{l}\text { Suppresses growth of native trees, forms } \\
\text { impenetrable thickets on rangeland and limits } \\
\text { access to water }\end{array}$ \\
\hline $\begin{array}{l}\text { Acacia mearnsii } \\
\text { (Black wattle) }\end{array}$ & + & + & $\begin{array}{l}\text { Outcompetes native plants lowers biodiversity } \\
\& \text { increased water loss }\end{array}$ \\
\hline $\begin{array}{l}\text { Acacia polyacantha } \\
\text { (White thorn) }\end{array}$ & + & + & Suppresses native plant species \\
\hline
\end{tabular}

Source: Author's computation, 2009

\section{Discussion}

\section{What are invasive plant species?}

Although there is a growing global awareness of invasive plants and the disasters they cause, little attention has been paid to them and few studies have been conducted in tropical Africa (Binggeli et al., 1998; Wakibara \& Mnaya 2002).

Invasive plants are regarded as species that are capable of penetrating and replacing the existing indigenous vegetation of a location. Classically invasive plants are defined as exotic plants that have been introduced in a location, either intentionally or unintentionally, and that reproduce and spread on their own (Rejmanek, 1995). In East Africa most of the invasives were introduced 
intentionally. For instance, the obnoxious mesquite was introduced in the Kenyan drylands through the initiatives of the Food and Agriculture Organization (FAO) and the Kenya Forestry Research Institute to curb desertification and increase fuelwood (Pasiecznik et al., 2006).

Four key features are associated with invasive plants: (1) they show prolific seeding and early age of first reproduction, (2) have unpalatable foliage, (3) can easily establish in degraded environments, and (4) have an ability to regenerate profusely from direct seeds, stems or roots. These features make them good competitors amongst other plant species and allow their survival and abundant establishment.

There is a link between invasive plants, ecological integrity and human social livelihoods. First and foremost, maintaining the integrity of ecological systems is an important part of achieving sustainable use of natural resources. Ecological integrity is often disrupted by invasive species which encroach vigorously upon native species and degrade ecosystem services such as soil conservation and water catchment protection, thus causing severe damage to the economy and social livelihoods (Sudmeier-Rieux \& Ash, 2009). Indeed the Millennium Ecosystem Assessment (MA), an international assessment initiative, has shown strong links between human wellbeing, human security, livelihoods and intangible benefits such as equality and freedom of choice with ecological or ecosystem services. The MA also highlights that a number of human activities (that include invasive species) degrade the ecological integrity of ecosystems (Sudmeier-Rieux \& Ash, 2009).

\section{Time lags and slow onset disaster characteristics}

What are the reasons for the time lags between the introduction of the plant species and their subsequent disaster? Hobbs and Humphries (1995) suggest two grounds: (1) species take some time to adapt to new environments, i.e. genotypic adaptation, and (2) species with exponential growth go unnoticed until populations are at critical sizes. Time lags are affected by changes in abiotic and biotic factors. Large and dramatic disturbances caused by abiotic factors (e.g. fires, deforestation and floods) often create new conditions for prolific regenerations or invasion windows'. For instance, Cecropia peltata (the Trumpet tree), was first introduced in Ivory Coast as a shade tree for coffee plantations in 1910, but spread over a radius of $100 \mathrm{~km}$ between 1950 and 1960 following heavy deforestation. Its spread enhanced biodiversity loss and caused disastrous disintegration of the native forest ecosystem. Biotic determinants of time lags may include factors associated with seeds and seedling dynamics such as the introduction of animal pollinators and changes in the population of grazing animals and their trampling intensities.

\section{How do plant invasions occur?}

Invasion opportunities largely occur or follow disturbances in an ecosystem. Disturbances are common in East African drylands and are largely caused by human agro-pastoralism activities of shifting cultivation. This is a process whereby nomadic inhabitants cultivate crops on an unoccupied fertile piece of land and later move off it when the land loses soil fertility. Periodic shifting from unfertile lands to uncultivated fertile lands is a continuous cycle of movement that has, in recent times, increased in frequency due to population increase. Subsequently this 
has caused patches of highly degraded or disturbed areas (having invasive tree and shrubs) within the drylands that were previously occupied by native trees. Land disturbances release resources which invasive trees and shrubs exploit (Davis et al., 2000). Although both the native and invading plant species respond to disturbances it is the differences in their responses that determine if invasion occurs or not (Chesson \& Huntly, 1997). For example, an invasive plant may show stronger positive response to a disturbance because it possesses an advantage at a particular time or place or may have a beneficial characteristic such as a strong ability to colonize a certain habitat. In Tanzanian drylands, the highly colonizing and invasive White thorn tree places vast amounts of seeds in the soil (or a rich soil seed bank) unlike other species (Obiri et al., 2010). Another example is Mesquite which survives in disturbed moisture-stressed environments of Kenya and Ethiopia largely because of its deep roots that reach the low watertables (Pasiecznik et al., 2001).

Invasion opportunities also arise from disruptions of the historical pattern of resource supply and consumption (Sher \& Hyatt, 1999). These disruptions, mostly caused by human activities, include alteration in patterns of fire regimes (D'Antonio, 2000), wood harvesting, nutrient enrichment (Jefferies, 2000) and climate change (Vitousek et al., 1997; D'Antonio, 2000). Because they are not adapted or rarely occur in disturbed ecosystems, native species are likely to decline in numbers under disrupted patterns of resource supply and consumption. This results in disused resources that become entry points for invaders. On the other hand, invaders, such as those found in human-disturbed environments, may already have adaptations suited for pattern-disrupted environments (Drake \& Mooney, 1989). The northern lowlands of Ethiopia are an example whereby, following land degradation, Acacia nilotica (Egyptian thorn) trees have declined in density and been replaced by the drought resistant Mesquite (Pasiecznik et al., 2001).

\section{Invasions and plant community dynamics}

Plant invasions can perhaps be best explained within a framework of plant community ecology (Shea $\&$ Chesson, 2002) where various viewpoints of biological invasions are considered. These include the characteristics of the plant invaders (Kolar \& Lodge, 2001), the characteristics of the invaded plant community (Lonsdale, 1999), resource availability (Davis et al., 2000) and the role of natural enemies (Keane \& Crawley, 2002). Invasions occur through three stages: transport of invaders to new sites, establishment and population increase of the invaders in the new sites and their secondary spread from initial populations to other sites. All three stages have a vital link or input of human involvement as it is man who introduces the species into the community, in the first instance, and facilitates its spreading. Furthermore the manifestation of hazards to disasters occurs as a result of the increased presence of man in areas previously sparsely populated. Undoubtedly the establishment of invader plants at a location depends on their successful arrival in that locality in the first instance (Kolar \& Lodge, 2001). Their subsequent establishment, however, depends on the way they interact with biotic and abiotic factors at the new location and particularly their ability to exploit opportunities available at the new location. The two most basic requirements of invaders are opportunities for obtaining resources for growth and opportunities for escaping natural enemies. The way a species responds 
to these opportunities (both of which vary in time and space) determines the species' invading ability. It also determines the species' management and DRR strategies to control it. These factors are discussed in the sections below.

\section{Invading opportunities related to resources}

Invasion occurs if a plant species has a better ability than native plant species to extract resources in a location or if its cost of maintenance is much lower than that of native species (Shea $\&$ Chesson, 2002). This does not mean that plant invaders have better or superior structural systems (e.g. roots and leaves) that enable them to manufacture more food and grow faster than the native plants. However, they may have a superior response to particular conditions relating to resources such as an ability to extract resources even as the resources fluctuate with time or space (Chesson, 2000). In certain cases an invasion is facilitated by an ability of the invader to change a small spatial area around itself to its own advantage. For instance, some invader plants are known to produce poisonous (or allelopathic) compounds in the soil roots that kill and lower densities of its neighboring native species (Callaway \& Aschehout, 2000). This phenomenon is also thought to occur with Mesquite (Pasiecznik et al., 2001).

\section{How do we manage these plant invasions and their accompanying disasters?}

One question is often asked in regard to the DRR of invasive plants. Is it possible to predict species that are likely to be invasive and hence become a risk? Despite the currently substantial information compiled on biological invasions there are very limited pointers for species likely to be invasive and a risk. The general tendency has been to consider the plant species that first occupy the open non-inhabited areas that often have harsh conditions such as dry rocky ground devoid of moisture. These plants are referred to as pioneer species (as they break new ground) and are the likely invaders. However, given the right locations, climate and environment any species is potentially invasive (Shea \& Chesson, 2002). Perhaps the best single DRR initiative for predicting invasiveness is to consider the behaviour of invasive species in other regions (Reichard, 1994). If a species is being considered for introduction in a given region and it is a known invasive in second region elsewhere, then the species is likely to be invasive in the region meant for introduction if the two regions have similar environmental characteristics. In other words, once an invader often an invader. In this case it is of paramount importance that checklists of all species listed as invasive be available and consulted at all time in programmes of tree planting whether for ornamental or economic purposes. Furthermore, these checklists need updating particularly for the areas that previously were sparsely populated but now have increased human immigration and are thus more likely to face disasters.

A second DRR question also often asked is: how can resistance to invasive plants be increased. Various studies suggest that invasion resistance increase with species diversity (Knops et al., 1999; Naeem et al., 2000). This relationship is explained by the empty niche hypothesis (Simberloff, 1995) where under low species diversity resources are not efficiently exploited because of a scarcity of species with ideal niches. Therefore niche opportunities exist for any invading species. Consequently having many different species in a habitat or high biodiversity is one approach to invasion resistance. 
Traditionally, the management of overgrown vegetation in dry forests is largely done through fire, grazing and browsing (Chidumayo, 1997). Fire is probably the most important as it has the most significant effect on seedling dynamics. Although fire is necessary for resprouting in East African drylands (Luoga et al., 2004) under intense conditions or frequent occurrences it causes seedling mortality, species loss and therefore increases opportunities for invading species. The fiercest fires occur in the late dry seasons when conditions are most favourable (i.e. when there is a high quantity of excessively dry litter collected on the forest floor). Such fires should be monitored and discouraged as they are very destructive and greatly contribute to increased opportunities for plant invasion. As a DRR initiative there is a need for a preparedness mechanism to ensure that the old dead stems and branches are not left piling up on the forest floor, but are removed, as they increase the fuel load during fire outbreaks.

\section{Conclusion}

Invasive plant species are hazards that have shown negative environmental and socio-economic impacts in East African drylands. They have degraded the environment and led to serious impacts on human wellbeing such as reduced availability of goods and services for local communities, increased spread of diseases and reduced economic opportunities. This, in turn, has led to loss of livelihoods, and reduced food security. Among the most serious of cases is the Mesquite tree that has devastated social livelihoods of many dryland communities in Kenya and even led to constitutional court cases between local communities and the Kenyan government. In both Kenya and Tanzania key legislations (such as the EMCA, the Forest and Plant Protection Acts) and institutions such as NEMA and the MENR monitor and control invasive species, however their outcomes have not been successful. The invasive plants related disasters have risen as communities have progressively moved into the drylands and remained ill-prepared to cope with the hazards. For instance, in the Baringo area the population was 210,000 when the mesquite was introduced around 1986 but by 2006 it had risen to 540000 , meaning that more people were exposed to hazards and thus disasters were likely to occur.

How do we combat invasive species? Like most environmental disasters, environmental management is central to building the resilience of communities and nations under the Hyogo Framework for Action (HFA), especially HFA priority 4. Therefore, environmental-based DRR policies, practices and guidelines need to be an integral part of managing the drylands. This includes, first, incorporate wise land-use planning whereby irregular disturbances such as random fires and the traditional dry season woodland burning that destroys existing vegetation are reduced. Secondly, since most invasive plants are introduced from foreign regions, it is critical to identify, assess and monitor phytosanitary risks of plant species being introduced into the country and drylands. Introductions should be preceded with counter-checking for any disaster-effects that a plant, intended for introduction, may have caused in an environment similar to where it is intended for introduction. Thirdly, establishing early warning systems and other preparedness measures such as ensuring that the fuel wood load in the dry forest floors does not accumulate as this enhances intensities of fires that burn and open up habitats for invasive plants. Fourth, it is important to strengthen the institutions of environmental management, mechanisms and capacities at different levels (especially at the community level) 
so as to systematically build resilience towards invasive species' hazards. In this regard the National Environmental Management Authority in Kenya and the Ministry of Environment and Natural Resources in Tanzania need to increase their efforts regarding environmental education issues such as awareness of invasive species among local communities. Although this study took an East African approach, it was limited in scope as the drylands of Uganda, which are part of the region, were not included. Thus it is recommended that future studies need to explore other regions such as Uganda and also increase the number of regions under study in each country.

\section{References}

BINGGELI, P. 1989. The ecology of Maesopsis invasion and dynamics of the evergreen forest of the East Usambaras, and their implications for forest conservation and forestry practices. (In Hamilton, A.C. \& Bensted-Smith, R., eds. Forest conservation in the East Usambara Mountains, Tanzania. Gland: IUCN. p. 269-330.)

BINGGELI, P., HALL, J.B. \& HEALEY, J.R. 1998. A review of invasive woody plants in the tropics. School of Agricultural and Forest Sciences Publication Number 13, University of Wales, Bangor. Available at: http://www.safs.bangor.ac.uk/iwpt

CALLAWAY, R.M. \& ASCHEHOUT, E.T. 2000. Invasive plants versus their new and old neighbors: a mechanism for exotic invasion. Science, 290(5491):521-523, 20 Oct.

CHESSON, P. 2000. Mechanism for maintenance of species diversity. Annual Review of Ecological System, 13:343-366, Nov.

CHESSON, P. \& HUNTLY, N. 1997. The roles of harsh and fluctuating conditions in the dynamics of ecological communities. American Naturalist, 150(5):519-553, Nov.

CHIDUMAYO, E.N. 1997. Miombo ecology and management: an introduction. 2nd ed. London: Intermediate Technology Publications. $166 \mathrm{p}$.

D’ANTONIO, C.M. 2000. Fire, plant invasions and global changes. (In Mooney, H.A. \& Hobbs, R. J., eds. Invasive Species in a Changing World. Island Press. p. 65-94.)

DAVIS, T., GRIME, J.P. \& THOMPSON, K. 2000. Fluctuating resources in plant communities: a general theory of invisibility. Journal of Ecology, 88:528-534.

DRAKE, J.A. \& MOONEY, H.A. 1989. Biological invasions: global perspectives. Hoboken N.J: Wiley. 550 p.

ENVIRO-CONSERVE. 2010. Alarming decline in biodiversity: invasive species a threat to world biodiversity and the global economy. Available at: http://www.enviroconserve.org/article.php?Article=106 \&Topic $=4 \&$ Subtopic $=3 \&$ Mag=25 Date of access: 10 July 2010 .

HOBBS, R.J. \& HUMPHRIES, S.E. 1995. An integrated approach to the ecology and management of plant invasions. Conservation Biology, 9(4):761-770.

IUCN (International Union for the Conservation of Nature). 2010. Are protected areas in Africa protecting invasives species? Available at: http://www.cabi.org/Uploads/File/GISP/Invasive+Species+and+P rotected+Areas+Press+Release+FINAL+DRAFT.pdf Date of access: 7 July 2010. 
JEFFERIES, R.L. 2000. Allochthonous inputs: integrating population changes and food web dynamics. Trends in Ecological Evolution, 15(1):19-22, Jan.

KEANE, R.M. \& CRAWLEY, M.J. 2002. Exotic plant invasions and the enemy release hypothesis. Trends in Ecological Evolution, 17(4):164-170, Apr.

KENYA LAW REPORT. 2007a. Petition case 466 of 2006. Charles Lekuyen Nabori and nine others versus Attorney General and three others 2007 and eKLR. Available at: http://www.kenyalaw.org/ bench_cases/62126.pdf Date of access: 18 Sept. 2010.

KENYA LAW REPORT. 2007b. Civil suit 115 of 2006. Samson Lereya Charles and 800 others versus Attorney General and two others 2006 eKLR. Available at: http://www.ecolex.org/server2.php/libcat/ docs/COU/Full/En/COU-144017E.pdf Date of access: 18 Sept. 2010.

KNOPS, J.M.H., TILMAN, D.H., NAEEM, S., MITCHELL, C., HAARSTAD, K., RITCHIE, M., HOWE, K., REICH, P., SIEMANN, E. \& GROTH, J. 1999. Effects of plant species richness on invasion dynamics, disease outbreaks, insect abundance, and diversity. Ecological Letters, 2(5):286-293, Sept.

KOLAR, C.S. \& LODGE, D.M. 2001. Progress in invasion biology: predicting invaders. Trends in Ecological Evolution, 16(4):199-204, Apr.

KRUEGER, R. 2007. Ignorance is bliss or maybe denial is bliss? Invasive Species. Available at: http:// columbia.uwex.edu/ag/conservation/documents/article53.pdf Date of access: 16 Sept. 2010.

LONSDALE, W.M. 1999. Global patterns of plant invasions and concept of invisibility. Ecology 80:1522-1536.

LUOGA, E., WITKOWSKI, E.T.F. \& BALKWILL, K. 2004. Regeneration by coppicing (resprouting) of miombo (African savanna) trees in relation to land use. Forest Ecology and Management, 189(1-3):2335. Feb.

MOONEY, H.A., MCNEELY, J.A., NEVILLE, L., SCHEI, P.J. \& WAAGE, J. 2003. Invasive alien species: Searching for solutions. Washington: Island Press.

NAEEM, S., KNOPS, J.M.H., TILMAN, D.H., HOWE, K., KENNEDY, T. \& GALE, S. 2000. Plant diversity increases resistance to invasion in the absence of covarying extrinsic factors. Oikos, 91(1):97-108, Oct.

OBIRI, J., HEALEY, J. \& HALL, J.B. 2010. Composition, structure and regeneration of Miombo Forest at Kitulangalo, Tanzania. (In Bongers, F. \& Tennigkeit, T. eds. Degraded Forests in Eastern Africa - management and restoration. London: Earthscan Publishers. p. 109-122.)

PASIECZNIK, N., CHOGE, S., MUTHIKE, G., CHESANG, S., FEHR, C., BAKEWELLSTONE, P., WRIGHT, J. \& HARRIS, P. 2006. Putting knowledge on Prosopis into use in Kenya. Pioneering Advances in 2006. KEFRI, Nairobi, Kenya and HDRA, Coventry, UK. $13 \mathrm{p}$.

PASIECZNIK, N., FELKER, P., HARRIS, P.J., HARSH, L.N., CRUZ, G., TEWARI, J.C., CADORET, K. \& MALDONADO, L.J. 2001. The Prosopis juliflora - Prosopis pallida Complex: A Monograph. Coventry: HDRA

PIDOT, J. 2005. The applicability of nuisance law to invasive plants: can common law liability inspire government action? Virginia Environmental Law Review, 24:183.

PIMENTEL, D. 2002. Biological invasions: economic and environmental costs of alien plant, animal, and microbe species. Boca Raton: CRC Press. 384 p. 
REICHARD, S. 1994. Assessing the potential of invasiveness in woody plants introduced in North America. Seattle: University of Washington Press (Dissertation - Ph.D.).

REJMANEK, M. 1995. What makes a species invasive? (In Pysek, P., Prack, K., Rejmanek, M. \& Wade, M., eds. Plant invasions: general aspects and special problems. Amsterdam: Academic Publishers.)

SHEA, K. \& CHESSON, P. 2002. Community ecology theory as a framework for biological invasions. Trends in Ecological Evolution, 17(4):170-176, Apr.

SHER, A.A. \& HYATT, L.A. 1999. The disturbed resource-flux invasion matrix: a new framework for patterns of plant invasion. Biological Invasions, 1(2-3):107-114.

SIMBERLOFF, D. 1995. Why do introduced species appear to devastate islands more than mainland areas? Pacific Science, 49(1):87-97, Jan.

SUDMEIER-RIEUX, K. \& ASH, N. 2009. Environmental guidance note for disaster risk reduction: healthy ecosystems for human security. Rev ed. Gland, Switzerland: IUCN. 34 pp. VITOUSEK, P.M., D’ANTONIO, C.M., LOOPE, L., REJMANEK, M. \& WESTBROOK, R. 1997. Introduced species: a significant component of human-caused global change. New Zealand Journal of Ecology 21(1):1-16.

WAKIBARA, J.V. \& MNAYA, B.J. 2002. Possible control of Senna spectabilis(Caesalpiniaceae), an invasive tree in Mahale Mountains National Park, Tanzania. Oryx 36:357-363, Nov.

WISNER, B. \& GAILLARD, J.C. 2009. An introduction to neglected disasters. Jàmbá: Journal of Disaster Risk Studies, 2(3):151-158, Dec. 